\title{
Research on the Influence of Entrepreneurial Failure Learning on Serial Business Intention
}

\author{
Jiang Hui \\ Department of business administration, Wuhan University of Technology, Wuhan, China \\ 565927697@qq.com
}

\begin{abstract}
Keywords: Serial Business Intention, Entrepreneurial Failure Learning, Logistic Regression Analysis
\end{abstract}

\begin{abstract}
This article will explore the intrinsic link between entrepreneurial failure learning and serial entrepreneurial intention. Based on the content of entrepreneurial failure learning proposed by scholar Cope, through interview method, questionnaire survey, using spss 25.0 for specific analysis to find out the key impact factors affecting entrepreneurs' serial entrepreneurial intention. It shows that in the factors affecting entrepreneurial failure learning, rethinking the reasons for entrepreneurial failure and rethinking the advantages and disadvantages of entrepreneurs are the main factors that influence entrepreneurs' follow-up entrepreneurial behavior.
\end{abstract}

\section{Introduction}

As a strong pillar of economic prosperity, technological innovation, and employment alleviation, entrepreneurship has been widely concerned by scholars at home and abroad. With the introduction of the national policy of encouraging entrepreneurship, the number of entrepreneurs has gradually increased, and competition among entrepreneurs has become increasingly fierce. According to relevant research, given the high risk of initial entrepreneurship, although every entrepreneur is eager to catch the success, the chances of success in the first venture are still very low [1]. According to a survey published by Fortune Magazine, the success rate of entrepreneurship on a global scale is less than $30 \%$, and entrepreneurial failure can even be seen as an indispensable part of the entrepreneurial process. A serial entrepreneur is an entrepreneur who has more than one entrepreneurial experience and starts another business after the end of the previous entrepreneurial activity [2], that is, an entrepreneur who has experienced another business after failing after starting a business. Studies have shown that most entrepreneurs will start their own business again after experiencing the failure of entrepreneurship. In the UK, the proportion of serial entrepreneurs among entrepreneurs is about 19\%-25\%; in Germany, the economic contribution of serial entrepreneur accounts for $18 \%$ of all entrepreneurs' economic contributions, and this figure is even close to $30 \%$ in Finland [3]. It can be seen that serial entrepreneurs occupy a proportion that cannot be ignored in the total number of entrepreneurs. At the same time, RAF [4] proposed that entrepreneurs mainly use the "Doing by Learning" approach to serial learning, and their subjective experience plays a very important role in the learning process. Entrepreneurs can constantly find ways to solve problems from failures and mistakes, or a program to discover and master useful knowledge and information to improve your entrepreneurial ability. Therefore, with the increasing number of serial entrepreneurs, it is necessary to explore the impact of entrepreneurs' failure learning on their intention of continuous entrepreneurship.

At present, the existing literature mainly studies the formation process of entrepreneurial intention from the theory of entrepreneurial self-efficacy [5]. This theory can effectively explain the entrepreneurial success of entrepreneurs who have succeeded in their self-efficacy and thus improve their serial entrepreneurial intention. However, it is impossible to explain the phenomenon that entrepreneurs who have failed in previous ventures still choose to carry out follow-up business after failing to reduce their self-efficacy [6]. The relevant theories about serial entrepreneurs' failure to learn entrepreneurship are not mature enough to form a framework of learn entrepreneurship. The basic theory and the mechanism of entrepreneurial failure learning towards the entrepreneur's serial 
entrepreneurial intention is still in the black box.

Therefore, this article will explore the intrinsic link between entrepreneurial failure learning and serial entrepreneurial intentions in the context of scholar Cope's entrepreneurial failure. The eight influencing factors affecting the serial entrepreneurial intention are proposed, using statistical analysis methods to obtain the key impact factors affecting entrepreneurs' serial entrepreneurial intention. Thereby guiding the serial entrepreneurs' entrepreneurial failure learning behavior. This paper pays more attention to the formation and evolution of entrepreneurs' personal skills, knowledge accumulation and entrepreneurial ability from the failure of entrepreneurship to re-starting. The key factors of entrepreneurial intention make up for the shortcomings of classic entrepreneurial management, entrepreneurs and other theories in explaining the failure of learning behaviors of serial entrepreneurs.

\section{Entrepreneurial failure learning}

\subsection{Definition of entrepreneurial failure}

When defining the failure of entrepreneurship, many scholars do not define the concept of entrepreneurial failure clearly, which is mainly divided into the following three viewpoints.

2.1.1 Results

Shepherd et al. defined the failure of entrepreneurship as the income of the startup company, the turnover cannot meet the operating cost needs and cannot get enough asset financing, resulting in the phenomenon of having to liquidate or sell the enterprise [7].

\subsubsection{Reasons}

The reason view emphasizes the reasons for the failure of the enterprise. Headd [8] believe that the entrepreneur may voluntarily stop the business because of retirement, interest in other business opportunities, and cannot be defined as entrepreneurial failure. It should be defined as the termination of business; the failure of entrepreneurship is more forced to terminate the enterprise, so the termination of entrepreneurship cannot be regarded as a failure of entrepreneurship.

\subsubsection{Expectation}

Some scholars have suggested that the failure of entrepreneurship is not necessarily the termination of new enterprises or the interruption of business operations. It can also be regarded as a state in which the actual performance of the entrepreneurs and the expected goals of the entrepreneurs deviate from the establishment and management process of the entrepreneurs. Cannon [9], based on the original intention of the company, defines entrepreneurial failure as the company's operation deviates from the original expectations or fails to achieve the expected results in the creation process.

This paper will take a relatively objective view of the standard results, that is, the failure of entrepreneurship means that the company cannot be operated serially due to one or more complicated factors, and is forced to close, go bankrupt or be sold.

\subsection{Reasons for entrepreneurial failure}

In order to draw lessons, transform the thinking model and improve abilities from the process of entrepreneurial failure, entrepreneurs must pay attention to the reasons for entrepreneurial failure. The cause of entrepreneurial failure is inextricably linked to the content of entrepreneurial failure learning, so it is especially important to explore the reasons for entrepreneurial failure.

Under the resource-based theory, Brush et al. believe that resources are an important foundation for the establishment and rapid development of enterprises. The main factors of entrepreneurial failure are the lack of venture capital, the lack of institutions and the lack of human resources [10]; Zacharakis and other scholars in their research discovered that, $75 \%$ of investors attributed the failure of entrepreneurship to uncontrollable external factors such as vicious competition in the market and the lack of external mechanism, while entrepreneurs blamed it for some intrinsic factors such as irrational level of enterprise management, adopted the wrong business model, their own overconfidence and inexperience [11]. Therefore, this paper divides the failure of entrepreneurship into external attribution and internal attribution, which are respectively explained as follows. 
External environmental factors are uncontrollable. PEST analysis can divide macro environmental analysis into political environment, economic environment, social environment and technical environment. According to Qin Yong, political aspects include political systems, government policies, national industrial policies, relevant laws and regulations, etc.; social aspects include population, values, moral standards, etc.; economic aspects include economic development level and scale, growth rate, government revenue and expenditure, inflation rate, etc.; technical aspects include breakthroughs in high-tech, process technology and basic research [12].

Under the influence of internal environmental factors, from the perspective of interpersonal behavior, the author explores the causes of entrepreneurial failures by using the AIV model (A, affection emotional connection; I, identification identity; V, value, contribution value). The reasons for the failure can be attributed to three parts: enterprise resources, business model and management system. In the AIV model, the entrepreneur is not only a single individual, but also the center of a relationship network. The network of resources meets the first layer: emotional connection. The second layer includes the understanding of entrepreneurs and their employees about the value, goals, and management philosophy of the company. Its essence is the individual's recognition of the business model and values of the company. The third level is value contribution, that is, the contribution of entrepreneurs and their employees to the company. Each employee needs to contribute unique value, which requires the entrepreneurs themselves and employees to trust the management system.

In summary, this paper argues that the degree of entrepreneurial failure learning is regulated by failure attribution, and internal attribution will have a greater impact on entrepreneurial failure learning. Based on the comprehensive reference to the three elements of Timmons entrepreneurship (business opportunities, resources and entrepreneurial teams), the factors affecting entrepreneurial failure are summarized into the following four points: complementary resources, complementary capabilities, complementary roles and complementary teams. Failure to meet these factors will be seen as a cause of failure for entrepreneurs.

\subsection{The content of entrepreneurial failure learning}

Looking back at the relevant literature, it is found that there is a big difference in the division of learning content in entrepreneurial failure. Scholars such as Yu Xiaoyu proposed that entrepreneurial failure learning includes three aspects of self-learning, internal learning and external learning [13]; Li Guiquan and other scholars believe that entrepreneurs can learn from entrepreneurial failure according to changing their own behavior and organizational policies after experiencing entrepreneurial failure [14]; The content of entrepreneurial failure learning is divided by Jason Cope into four aspects: First, the study of the "self", including understanding the advantages of itself , shortcomings, skills, attitudes, beliefs and future development directions; second, the study of "enterprise", such as understanding the advantages and disadvantages of the company and the reasons for the failure of entrepreneurship; the third is the study of "relationship", including The management of internal and external relationships and the skills to improve these relationships; the last one is the study of "management", such as how to operate and control new businesses more effectively when the company contacts the outside world. Among them, the study of the "self" is the core of entrepreneurial failure learning [15]. These four aspects of learning take into account the four factors of complementary factors: complementary resources, complementary skills, complementary personality and team complementation. The difference in the content of the above-mentioned entrepreneurial failure learning content is caused by the difference between the research situation and the objects. Because the entrepreneurial behavior is fragmented and diverse, the learning content of the entrepreneurial failure is complicated.

This paper believes that entrepreneurial failure learning refers to the influence of entrepreneurs' acquired entrepreneurial skills and knowledge acquired through entrepreneurial failure learning on re-initiation of entrepreneurship. Serial entrepreneurs can learn from the experience of previous entrepreneurial failures to guide the next entrepreneurial behavior, based on this, this paper explores the influence of failure learning on entrepreneurs' serial entrepreneurial intention. 


\subsection{Serial entrepreneurial intention}

Bird's "initiative of entrepreneurship" refers to a psychological state that promotes entrepreneurs to accomplish their entrepreneurial goals and generate input factors to form entrepreneurial behaviors [16]. Due to the complexity and uniqueness of serial entrepreneurs, there is no clear definition of serial entrepreneurial intention in China, but the meaning of serial entrepreneurial intention is basically agreed, that is, "serial entrepreneurial intention" is defined as the entrepreneur has experienced one or more entrepreneurial practice (success or failure), there is still tendencies to start a business again.

\section{Research design and method}

\subsection{Open coding}

This study designed an interview outline on the impact of entrepreneurial failure learning on the intention of serial entrepreneurship, and selected two serial entrepreneurs with more than ten years of entrepreneurial experience with entrepreneurial failure to conduct in-depth interviews to explore the complex rules behind their behavior from entrepreneurial failure to serial entrepreneurship.

The case data was obtained from the face-to-face interview records with the entrepreneurial team. By guiding the entrepreneurs to recall the psychological process and behavioral activities from the failure of starting a business to starting a new business, the interview data were sorted out by encoding and classification, and finally 8 concepts affecting the intention of serial entrepreneurship were extracted in Table 1.

Table 1. Coding process of entrepreneurial failure learning

\begin{tabular}{|c|c|c|}
\hline entrepreneur & Citation example & $\begin{array}{c}\text { Coding: } \\
\text { conceptualization }\end{array}$ \\
\hline \multirow{5}{*}{ Mr. Dong } & $\begin{array}{l}\text { 1. In all fairness, I am too confident and rarely obey the } \\
\text { opinions of others, this does need to be corrected. I was so } \\
\text { bloody at the time, I hope that I can still manage the } \\
\text { company as a manager in the future. I hope that I can do } \\
\text { better in the future. }\end{array}$ & Cognitive ability \\
\hline & $\begin{array}{l}\text { 2. I will evaluate it from an objective perspective. What I } \\
\text { did was wrong. I will learn to do what others do. I will } \\
\text { notice what I am missing, at that time, I laid a good } \\
\text { foundation. }\end{array}$ & Skill improvement \\
\hline & $\begin{array}{l}\text { 3. It is hard to succeed in a cross-industry, it is not the } \\
\text { industry you are familiar with. It takes time to learn and } \\
\text { train, however in the end you may not be able to adapt to } \\
\text { the industry. }\end{array}$ & Failure reflection \\
\hline & $\begin{array}{l}\text { 4. It is very important to find out the strengths and } \\
\text { weaknesses of the company. The key is to grasp how to } \\
\text { exert the strengths of the company and make up the short } \\
\text { board. This has played a big role in my future } \\
\text { entrepreneurship. }\end{array}$ & $\begin{array}{l}\text { Enterprise } \\
\text { Competitiveness } \\
\text { Analysis }\end{array}$ \\
\hline & $\begin{array}{l}\text { 5. I also know how to get through the difficulties and grow } \\
\text { up, and how to improve the performance to manage the } \\
\text { team. In the future, I think I can successfully overcome the } \\
\text { difficulties and realize my entrepreneurial dream. }\end{array}$ & Future outlook \\
\hline Mr. Liu & $\begin{array}{l}\text { 1. We lost opportunities because we couldn't provide } \\
\text { products within our supplier company. At the same time, } \\
\text { the auto industry has a low investment and a long period of } \\
\text { high investment, so there is no need to do it. }\end{array}$ & External relationship \\
\hline
\end{tabular}




\begin{tabular}{|c|c|}
\hline $\begin{array}{l}\text { 2. In the past, our company's management supported too } \\
\text { many people. Mainly, it seems to me that it is very difficult } \\
\text { to recruit technicians and managers. Then I decided to cut } \\
\text { jobs and reduce the company's costs. Experience tells me } \\
\text { that the growth of people will bring the growth of enterprise } \\
\text { resources. }\end{array}$ & Management ability \\
\hline $\begin{array}{l}\text { 3. In fact, we didn't get any orders that year, but I practiced } \\
\text { every aspect of myself. This is a visionary idea. I know I } \\
\text { have many shortcomings, and I must improve through } \\
\text { experience. }\end{array}$ & Cognitive ability \\
\hline $\begin{array}{l}\text { 4. Speaking of experience, a company needs to be very } \\
\text { successful. These three elements are essential, Customers, } \\
\text { products and teams. Our customers and products were } \\
\text { good, but we didn't have a good team. I've been building a } \\
\text { team and I've spent a lot of time and energy rebuilding and } \\
\text { building the team. }\end{array}$ & Internal relationship \\
\hline
\end{tabular}

Based on the above analysis, the study draws the entrepreneurial failure learning entry for serial entrepreneurs in figure 1. This entry is basically in line with the entrepreneurial failure learning content proposed by Cope.

Cognitive ability, Skill improvement, Failure reflection, Enterprise

Competitiveness Analysis, Future outlook, External relationship, Management ability, Internal relationship

Figure 1. Entrepreneurial failure learning content entry

\subsection{Questionnaire design}

The author mainly based on Cope's entrepreneurial failure learning content [15], combined with the previous interview results, the entrepreneurial failure learning questionnaire was compiled, which mainly included four aspects of "self-learning", "learning about enterprise", "learning about corporate relations" and "learning about management". According to the meaning of the topic, eight exploratory factors are proposed: deepening your own understanding, strengthening your own skills, reflecting on the reasons for the failure of entrepreneurship, rethinking the advantages and disadvantages of the enterprise, coordinating the external network of enterprises, optimizing the internal relationship network of enterprises, improving the management ability of enterprises, and an understanding of the future direction of development, Corresponding to 8 concepts of cognitive ability, skill improvement, failure reflection, enterprise competitiveness analysis, external relationship, internal relationship, management ability, and future outlook. It has a total of 27 options.

The scoring method adopted by the questionnaire is the Liken five-point metric. The expression of the score is set to be strongly disagree, disagree, general, agree, and totally agree, assigning 1 point, 2 points, 3 points, 4 Points, 5 points respectively. The higher the score, the better the learning after the failure of the venture.

Each respondent scored according to the personal situation of the statement description and the degree of conformity of their true perceptions, to ensure that the measurement results faithfully reflect the psychology of the respondent. According to the results of the literature research, combined with the feedback information of the questionnaire and the results of in-depth interviews with consecutive entrepreneurs, eight exploratory factors were combined, and the items designed by the questionnaire were listed in the following table 4.

\subsection{Study subjects}

The group case will cover different types of entrepreneurial groups such as returning migrant workers, college students, science and technology personnel, corporate elites, and retired military personnel. This study will issue questionnaires to the above entrepreneurial groups for data collection.

This questionnaire is issued in the form of a questionnaire for specific subjects, and gives the 
respondents a certain material reward. A total of 300 questionnaires were distributed in this study. After eliminating invalid questionnaires such as random filling, missing filling and regular answering, there were 269 remaining valid questions, and the effective rate was $89.67 \%$. Among them, there are $11(4.09 \%)$ people under the age of 20, $111(41.26 \%)$ between the ages of $21-30$, and $106(39.41 \%)$ between the ages of 31-40, 41 There are $32(11.90 \%)$ people between the ages of 50 and $9(3.35 \%)$ who are over the age of 50. As shown in Table 1. Most of the working years are between 2-10 years, and most of the academic qualifications are undergraduate degrees.

Table 2. Age distribution characteristics of participants

\begin{tabular}{cccccc}
\hline Age & $\begin{array}{c}\text { Frequency } \\
\text { (percentage) }\end{array}$ & Working years & $\begin{array}{c}\text { Frequency } \\
\text { (percentage) }\end{array}$ & $\begin{array}{c}\text { Educational } \\
\text { background }\end{array}$ & $\begin{array}{c}\text { Frequency } \\
\text { (percentage) }\end{array}$ \\
\hline $\begin{array}{c}\text { Under 20 } \\
\text { years old }\end{array}$ & $11(4.09)$ & 1 year and below & $34(12.64)$ & $\begin{array}{c}\text { High school and } \\
\text { below }\end{array}$ & $61(22.68)$ \\
$\begin{array}{c}21-30 \text { years } \\
\text { old }\end{array}$ & $111(41.62)$ & $2-5$ years & $115(42.75)$ & Bachelor & $173(64.31)$ \\
$\begin{array}{c}31-40 \text { years } \\
\text { old }\end{array}$ & $106(39.41)$ & $6-10$ years & $85(31.60)$ & master's degree & $34(12.64)$ \\
$\begin{array}{c}41-50 \text { years } \\
\text { old }\end{array}$ & $32(11.90)$ & $11-20$ years & $21(7.81)$ & PhD and above & $1(0.37)$ \\
$\begin{array}{c}\text { Over 50 years } \\
\text { old }\end{array}$ & $9(3.35)$ & $\begin{array}{c}\text { More than 20 } \\
\text { years }\end{array}$ & $14(5.21)$ & & \\
\hline
\end{tabular}

\section{Empirical analysis}

\subsection{Exploratory factor analysis}

Through the exploratory factor analysis of the collected questionnaire data, the principal component analysis method and the maximization variance were used to rotate the factors. The results are shown in Table 3 and Table 4. In this study, the following results show that the entrepreneurship failure learning questionnaire has a relatively good validity, which extracts a total of 8 common factors with the characteristic root value greater than 1 , and the factor loading of the questionnaire questions are all above 0.5 . In addition, the KMO suitability test value is 0.931 , and the Bartlett spherical test value is 7039.476, $\mathrm{df}=325$ and $\mathrm{p}<0.001$. At the same time, according to the meaning of the expression of the topic, the eight factors are named as "the deepening of your own understanding", "the strengthening of your own skills", "reflecting the reasons for the failure of entrepreneurship", "reflecting the advantages and disadvantages of the enterprise", and "coordinating the external relations of the enterprise", "Optimize the internal relationship network of enterprises", "Enterprise management capabilities", and "Cognition of future development direction".

Table 3. KMO and Bartlett test

\begin{tabular}{llr}
\hline KMO sampling suitability & & 0.931 \\
Bartlett sphericity test & Chi-square approximation & 7039.476 \\
& Degree of freedom & 325 \\
& significance & 0.000
\end{tabular}

Table 4. Component matrix after rotation ${ }^{\mathbf{a}}$

\begin{tabular}{|c|c|c|c|c|c|c|c|c|}
\hline & \multicolumn{8}{|c|}{ component } \\
\hline & 1 & 2 & 3 & 4 & 5 & 6 & 7 & 8 \\
\hline $\begin{array}{l}\text { q5.1 After the failure of entrepreneurship, I made a } \\
\text { profound analysis of my own strengths and weaknesses. }\end{array}$ & & & & & & 0.81 & & \\
\hline $\begin{array}{l}\text { q5.2 Entrepreneurial failure learning makes me still } \\
\text { confident in the follow-up business development }\end{array}$ & & & & & & 0.80 & & \\
\hline
\end{tabular}


q5.3 It's important for me to start my own business.

think about whether there is a proper solution.

q6.2 I will take the initiative to learn entrepreneurial

related knowledge and enhance entrepreneurial related skills.

q6.3 When I started my business again, I had more detailed entrepreneurial plans and ideas.

q7.1 The economic situation is not optimistic.

q7.2 The company lacks product design and marketing capabilities, and the products have no unique competitiveness.

q7.3 The development strategy of the enterprise is not reasonable, and the management ability is not enough.

q7.4 The market in my industry is competitive and saturated

q7.5 I do not understand the reason for the failure of the last business

q8.1 Have a deep understanding of the advantages and disadvantages of the environment in which the company is located

q8.2 Deep understanding of the advantages and disadvantages of the company's internal strengths and weaknesses q9.1 Strengthen the coordination of the relationship between enterprises and investors

q9.2 Strengthen the coordination of business and consumer relationships

q9.3 Strengthen the coordination of the relationship between enterprises and trading partners such as suppliers and distributors

q9.4 Strengthen the coordination of business and media relations

q9.5 Strengthen coordination of business and government relations

q10.1 Strengthen coordination of business and government relations

q10.2 Information sharing can be fully realized within the enterprise

q11.1 Enhance coordination and communication skills

q11.3 Enhance the ability of selecting and employing people

q12.1 The company has a clear vision of strategic $\quad 0.290$ development planning

q12.2 The company has a clear development planning business map

q12.3 The company has a clear plan for capacity building 0.231 


\subsection{Reliability test}

According to the results of exploratory factor analysis and the failure of entrepreneurship, the learning factors can be divided into "the deepening of self-knowledge", "enhancement of self-skills", "rethinking the reasons for entrepreneurial failure", "reflecting the advantages and disadvantages of enterprises", and "coordinating the externalities of enterprises". In terms of "relationship", "optimization of internal relationship network", "enterprise management ability" and "cognition of future development direction", in order to explore the reliability of research data, the author tests the coefficient of learning factors and uses Cronbach alpha coefficient as The results of the test factor reliability, the results are shown in Table 5, from the data results in the table can be seen, whether it is from the first-order factor of learning after the failure of entrepreneurship, or from the second-order factor or overall, in this In the study, the Cronbach alpha coefficient of the questionnaire was above 0.8 and had high reliability. Therefore, it can be said that the data of the questionnaire in this study is highly reliable and the data results are credible.

Table 5. Cronbach alpha coefficient test results of entrepreneurial failure learning factors

\begin{tabular}{|c|c|c|c|}
\hline variable & Second-order factor & First-order factor & $\begin{array}{c}\text { Cronbach alpha } \\
\text { coefficient }\end{array}$ \\
\hline \multirow{8}{*}{$\begin{array}{l}\text { Learning after } \\
\text { a failed startup } \\
(0.963)\end{array}$} & \multirow{2}{*}{$\begin{array}{l}\text { Self-learning } \\
(0.911)\end{array}$} & $\begin{array}{l}\text { Deepen your own } \\
\text { understanding }\end{array}$ & 0.922 \\
\hline & & $\begin{array}{l}\text { Strengthen your own } \\
\text { skills }\end{array}$ & 0.920 \\
\hline & \multirow[b]{2}{*}{ Corporate learning $(0.890)$} & $\begin{array}{l}\text { Rethinking the } \\
\text { reasons for the failure } \\
\text { of entrepreneurship }\end{array}$ & 0.902 \\
\hline & & $\begin{array}{l}\text { Rethinking the } \\
\text { advantages and } \\
\text { disadvantages of the } \\
\text { company }\end{array}$ & 0.924 \\
\hline & \multirow{2}{*}{$\begin{array}{l}\text { Relationship learning } \\
(0.924)\end{array}$} & $\begin{array}{l}\text { Coordinating external } \\
\text { relationships }\end{array}$ & 0.948 \\
\hline & & $\begin{array}{l}\text { Optimize internal } \\
\text { relationships }\end{array}$ & 0.943 \\
\hline & \multirow{2}{*}{$\begin{array}{l}\text { Management learning } \\
(0.914)\end{array}$} & $\begin{array}{l}\text { Business management } \\
\text { capability }\end{array}$ & 0.948 \\
\hline & & $\begin{array}{l}\text { Future development } \\
\text { direction }\end{array}$ & 0.933 \\
\hline
\end{tabular}

\subsection{Logistic regression analysis}

Based on the research experience of the predecessors, the author analyzes whether the factors in the entrepreneurial failure learning will affect the subsequent entrepreneurial intention of the research object, and whether the entrepreneurial loser will generate entrepreneurial behavior in the subsequent life after the relevant learning. It is a two-category variable (1 means that entrepreneurial behavior will be generated, 0 means no subsequent entrepreneurial behavior), so the author uses logistic regression analysis to analyze the impact of entrepreneurial failure learning factors on serial entrepreneurial intention. The results are shown in Table 6.

Table 6. Variables in the equation

\begin{tabular}{|c|c|c|c|c|c|c|c|c|c|}
\hline & & \multirow[b]{2}{*}{$\mathrm{B}$} & \multirow{2}{*}{\multicolumn{3}{|c|}{$\begin{array}{l}\text { Degree } \\
\text { of }\end{array}$}} & \multirow[b]{2}{*}{ significance } & \multirow[b]{2}{*}{ OR } & \multicolumn{2}{|c|}{$\begin{array}{l}95 \% \text { confidence } \\
\text { interval for OR }\end{array}$} \\
\hline & & & & & & & & $\begin{array}{l}\text { Lower } \\
\text { limit }\end{array}$ & $\begin{array}{l}\text { Upper } \\
\text { limit }\end{array}$ \\
\hline \multirow{2}{*}{$\begin{array}{l}\text { Step } \\
1^{\mathrm{a}}\end{array}$} & Deepen your own & 0.305 & 0.254 & 1.442 & 1 & 0.230 & 1.357 & 0.825 & 2.232 \\
\hline & $\begin{array}{l}\text { Strengthening of } \\
\text { your own skills }\end{array}$ & 0.093 & 0.215 & 0.187 & 1 & 0.665 & 1.097 & 0.721 & 1.671 \\
\hline
\end{tabular}




\begin{tabular}{|c|c|c|c|c|c|c|c|c|}
\hline $\begin{array}{l}\text { Rethinking the } \\
\text { reasons for the } \\
\text { failure of } \\
\text { entrepreneurship }\end{array}$ & 0.993 & 0.280 & 12.592 & 1 & 0.000 & 2.699 & 1.560 & 4.669 \\
\hline $\begin{array}{l}\text { Rethinking the } \\
\text { advantages and } \\
\text { disadvantages of } \\
\text { the company }\end{array}$ & 0.591 & 0.255 & 5.362 & 1 & 0.021 & 1.806 & 1.095 & 2.979 \\
\hline $\begin{array}{l}\text { Coordinating } \\
\text { external } \\
\text { relationships }\end{array}$ & 0.046 & 0.247 & 0.035 & 1 & 0.852 & 1.047 & 0.645 & 1.700 \\
\hline $\begin{array}{l}\text { Optimize internal } \\
\text { relationships }\end{array}$ & 0.084 & 0.207 & 0.164 & 1 & 0.685 & 1.087 & 0.725 & 1.631 \\
\hline $\begin{array}{l}\text { Business } \\
\text { management } \\
\text { capability }\end{array}$ & 0.316 & 0.255 & 1.539 & 1 & 0.215 & 1.372 & 0.833 & 2.260 \\
\hline $\begin{array}{l}\text { Future } \\
\text { development } \\
\text { direction }\end{array}$ & -0.183 & 0.209 & 0.769 & 1 & 0.380 & 0.833 & 0.553 & 1.254 \\
\hline constant & -6.258 & 1.231 & 25.820 & 1 & 0.000 & 0.002 & & \\
\hline
\end{tabular}

Note: a. Variables entered in step 1: deepen your own understanding, strengthen your own skills, reflect on the reasons for entrepreneurial failure, reflect on the strengths and weaknesses of the enterprise, coordinate the external relations of the enterprise, optimize the internal relationship of the enterprise, the ability of enterprise management, and the direction of future development.

From the data in the table, we can see that, reflecting on the causes of entrepreneurial failure and the advantages and disadvantages of enterprises are the main factors that affect whether the entrepreneurs will have subsequent entrepreneurial behaviors after failure. The main factor of entrepreneurial behavior, the logistic regression equation is:

Logit $(\mathrm{P}$ entrepreneurial failure follow-up entrepreneurial behavior $)=0.993 \mathrm{X}$ reflection on the reasons for entrepreneurial failure $+0.591 \mathrm{X}$ reflection on the advantages and disadvantages of the enterprise -6.258 .

That is, the reason for rethinking the failure of entrepreneurship has a significant impact on the serial entrepreneurial intention of entrepreneurial failure $(p=0.000<0.05)$, the regression coefficient is 0.993 , and the OR value is 2.699 . Rethinking on the advantages and disadvantages of enterprises also has a significant impact on the serial entrepreneurial intention of failure, the regression coefficient is 0.591 , and the OR value is 1.806 .

\section{Research results and discussion}

The purpose of this paper is to explore the influence of the change of entrepreneurs' personal skills and entrepreneurial ability on the intention of serial entrepreneurship, and to develop and design a learning failure scale for entrepreneurship, and to test the validity and reliability of the scale. Logistic regression analysis shows that in the factors affecting entrepreneurial failure learning, rethinking the reasons for entrepreneurial failure and rethinking the advantages and disadvantages of entrepreneurs are the main factors that influence entrepreneurs' follow-up entrepreneurial behavior after entrepreneurial failure learning. It has a more significant impact on entrepreneurs' serial entrepreneurial intentions.

The author hopes that through this research, entrepreneurs who are in the stage of entrepreneurial failure can be successfully engaged in entrepreneurial learning and form a continuous entrepreneurial intention. In addition, this article combines the content of entrepreneurial failure and serial entrepreneurial intentions, deepens the depth of research in the field of serial entrepreneurship, and also broadens the fields and boundaries of entrepreneurial failure and serial entrepreneurship research, and also makes up for other theories in explaining entrepreneurial failure. 


\section{References}

[1] Peng M W, Yamakawa Y, and Lee S H, Bankruptcy laws and entrepreneur-friendliness, Entrepreneurship Theory \& Practice, vol.34, pp. 517-530, 2010.

[2] Wright $\mathrm{M}$ et al, Venture capitalists and serial entrepreneurs [J], Journal of Business Venturing, vol.12, pp.227-249, 1997.

[3] Jose Plehn D, A theory of entrepreneurship [J], Small Business Economics, vol.35, pp. 377-398, 2010.

[4] RAE D, Entrepreneurial Learning: A Narrative-Based Conceptual Model [J], Journal of Small Business and Enterprise Development, vol.12, pp. 323-335, 2005.

[5] Hsudk, Wlklundj I, Cottonrd, Success, failure, and entrepreneurial reentry: an experimental assessment of the veracity of self-efficacy and prospect theory [J], Entrepreneurship Theory and Practice, vol.41, pp.19-47, 2015.

[6] Banduraa, Self-efficacy mechanism in human agency [J], American Psychologist, vol.37, pp. 122-147, 1982.

[7] Shepherd D A, Wiklund J, Haynie J M, Moving forward: Balancing the financial and emotional costs of business failure [J], Journal of business venturing, vol.24, pp.134-148, 2009.

[8] Headd B, Redefining business success: Distinguishing between closure and failure [J], Small business economics, vol.21, pp.51-61, 2003.

[9] Cannon M D, Edmondson A C, Confronting failure: Antecedents and consequences of shared beliefs about failure in organizational work groups [J], Journal of Organizational Behavior, vol.22, pp. 161-177, 2001.

[10]Brush C G, Greene P G, Hart M M, From initial idea to unique advantage: The entrepreneurial challenge of constructing a resource base [J], The academy of management executive, vol.15, pp. 64-78, 2001.

[11]Zacharakis A L, Meyer G D, DeCastro J, Differing perceptions of new venture failure: a matched exploratory study of venture capitalists and entrepreneurs [J], Journal of Small Business Management, vol.37, pp. 1-14, 1999.

[12] Qin Yong, Management theory, methods and practice, Tsinghua University Press, 2013.

[13] Yu Xiaoyu, Li Xueling, Yang Ruoyao, First-time entrepreneurial failure learning: an explanation from the entrepreneurial novice new business and industry characteristics [J], Journal of Management, vol.10, pp.77-83, 2013.

[14]Li Guiquan, Ge Jing, Xi Ximin and so on, The impact of failure experience on leadership behavior: based on the analysis of Shi Yuzhu's second-hand data [J], Journal of Management, vol.11, pp. 634-640, 2014.

[15]Cope, Jason, Entrepreneurial learning from failure: an interpretative phenomenological analysis [J], Journal of Business Venturing, vol.26, pp. 604-623, 2011.

[16]Bird B, Implementing Entrepreneurial Ideas: the case for intention [J], Academy of Management Review, vol.13, pp.442-453, 1988. 